\title{
Effect of filling fraction on the performance of sponge-based moving bed biofilm reactor
}

Xinbo Zhang ${ }^{\mathrm{a}}$, Xun Chen ${ }^{\mathrm{a}}$, Chunqing Zhang ${ }^{\mathrm{a}}$, Haitao Wen ${ }^{\mathrm{a}}$, Wenshan Guo ${ }^{\mathrm{b}}$, Huu Hao Ngo ${ }^{\text {** }}$

${ }^{a}$ Department of Environmental and Municipal Engineering, Bioprocess Centre For Sustainable Environment, Tianjin Key Laboratory of Aquatic Science and Technology, Tianjin Chengjian University, Jinjing Road 26, Tianjin 300384, China.

${ }^{b}$ Centre for Technology in Water and Wastewater, School of Civil and Environmental Engineering, University of Technology Sydney, Sydney, NWS 2007, Australia

* Correspondence author: Email address: ngohuuhao121@ gmail.com; Tel: +61 29514 2745; Fax: + 61 295147803

\section{Abstract:}

Cubic-shaped polyurethane sponges $(15 \times 15 \times 15 \mathrm{~mm})$ in the form of biofilm carriers were used in a moving bed biofilm reactor (MBBR) for treating synthetic domestic wastewater. Results indicated there was no significant difference in total organic carbon (TOC) and ammonia $\left(\mathrm{NH}_{4}{ }^{+}-\mathrm{N}\right)$ removal at different filling fractions. Three reactors exhibited high removal efficiencies of over $93 \%$ TOC and $95 \% \mathrm{NH}_{4}{ }^{+}-\mathrm{N}$ on average at an HRT of $12 \mathrm{~h}$ and aeration flow of $0.09 \mathrm{~m}^{3} / \mathrm{h}$. However, total nitrogen $(\mathrm{TN})$ removal and simultaneous nitrification and denitrification (SND) increased with increasing the filling fraction. TN removal averaged at $77.2,85.5 \%$ and $86.7 \%$ in $10 \%, 20 \%$ and $30 \%$ filling fraction reactor, respectively. Correspondingly, SND were $85.5 \pm 8.7 \%, 91.3 \pm 9.4 \%$ and $93.3 \pm 10.2 \%$. Moreover, it was observed that sponge carriers in the $20 \%$ filling fraction reactor achieved the maximum biomass amount per gram sponge, followed by the $10 \%$ and $30 \%$ filling fraction reactors.

Keywords: sponge based moving bed biofilm reactor, sponge carrier, simultaneous nitrification and denitrification, filling fraction

\section{Introduction}

With governments around the world implementing increasingly stringent effluent quality requirements and eutrophication controls, conventional pollutants as well as nutrients must be removed more efficiently. Therefore, advanced attached growth reactors such as the moving 
bed biofilm reactor (MBBR) have been developed for treating wastewater. To a large extent these have achieved a high degree of operational efficiency. The MBBR process was developed on the basis of conventional activated sludge and the best features of the biofilter process in Norway in the late 1980s and early 1990s (Ødegaard et al., 1994; Chen et al., 2008). Compared to the suspended biomass process, MBBR has certain advantages such as higher biomass concentration, higher chemical oxygen demand loading, strong tolerance to loading impact, longer sludge age, lower hydraulic retention time (HRT), higher volumetric removal rates, no sludge recirculation, relatively small area requirements and no sludge bulking problem (McQuarrie and Boltz, 2011; Leyva-Díaz et al., 2013).

The MBBR process has proved to be a very simple and efficient technology in municipal and industrial wastewater treatment strategies. In 2009 there were more than 600 MBBRs operating in 50 countries (Chen et al., 2015). Successful treatment is achieved by having the biomass grow on buoyant carriers that are slightly less dense than water and moving freely in the reactor's water. Consequently, the biofilm carriers in the MBBR play a major role in governing microbial attachment, as well as the type of reactor operation and process effectiveness. To date, various carriers have been introduced in the MBBR process, including polyethylene plastics, polyurethane sponge, polyvinyl alcohol gel, biodegradable polymer, granular activated carbon, polymer foam pads, nonwoven media, etc. (Rouse et al., 2007; Bertin et al., 2010; Guo et al., 2010; Nguyen et al., 2010; Chu and Wang, 2011a; Wu et al., 2012).

Of all the types of carriers, the sponge carrier is considered to be an ideal one for the attached growth media, in that it has a high porosity for microbial immobilization with the ability to deposit biomass on the sponge surface and inside the sponge pores (Guo et al., 2010). Nguyen et al. (2010) studied the effects of sponge size and type on treatment efficiency under aerobic conditions. Their results revealed there was no significant difference in the organic and nutrient removal rates between sponge types. Chu and Wang (2011b) used 
MBBRs filled with $20 \%$ sponge carriers to treat wastewater with a low $\mathrm{C} / \mathrm{N}$ ratio, concluding that total organic carbon and ammonium removal efficiencies were $90 \%$ and $65 \%$ at an HRT of $14 \mathrm{~h}$, respectively. Luo et al. (2014) investigated the removal of micropollutants in a sponge-based moving bed bioreactor. It emerged that polyurethane sponge indicated varying sorption capacities for micropollutants with a removal efficiency of $25.9 \%$ (carbamazepine) to 96.8\% (b-Estradiol 17-acetate) on average in the MBBR. In addition, as studied by Luo et al. (2015), the hybrid moving bed biofilm reactor-membrane bioreactor (MBBR-MBR) system filled with sponge cubes could effectively remove $80 \%$ of all hydrophobic compounds $(\log \mathrm{D}>$ 3.2) among the selected micropollutants at the HRTs of $24 \mathrm{~h}$ in the MBBR and $6 \mathrm{~h}$ in the MBR unit. Although some other studies have assessed the performance of sponge-based MBBR (Ngo et al., 2008; Nguyen et al., 2010; Chu and Wang, 2011a), to date, the effect of filling fraction on the nitrification and denitrification capacity of sponge-based MBBR has not yet been investigated. Further investigation on attached-growth biomass (AGBS) functions in biocarriers is thus necessary for developing an efficient bioprocessing operation.

Consequently, the objective of this study is to evaluate the effect of filling fraction on the sponged aerated-MBBRs in terms of: (i) the organic and nitrogen removals; (ii) nitrification rate and denitrification rate performance; and (iii) biomass growth on sponge carriers.

\section{Materials and methods}

\subsection{Synthetic wastewater}

The experiments were conducted with synthetic wastewater. The composition of synthetic wastewater in this study was referred to the study of Lee et al. (2003). It consisted of around 100-118 mg/L total organic carbon (TOC), 13-18 mg/L NH${ }_{4}{ }^{-} \mathrm{N}, 2.7-3.5 \mathrm{mg} / \mathrm{L}$ total phosphorus, $0.3-1.2 \mathrm{mg} / \mathrm{L} \mathrm{NO}_{3}{ }^{-} \mathrm{N}, 0.02-0.28 \mathrm{mg} / \mathrm{L} \mathrm{NO}_{2}{ }^{-}-\mathrm{N}$ and of a trace nutrient solution containing the following (mg/L): $\mathrm{MgSO}_{4} \cdot 7 \mathrm{H}_{2} \mathrm{O}, 5.07 ; \mathrm{CaCl}_{2} \cdot 2 \mathrm{H}_{2} \mathrm{O}, 0.368 ; \mathrm{MnCl}_{2} \cdot 7 \mathrm{H}_{2} \mathrm{O}$, 0.275; $\mathrm{ZnSO}_{4} \cdot 7 \mathrm{H}_{2} \mathrm{O}, 0.44 ; \mathrm{CoCl}_{2} \cdot 6 \mathrm{H}_{2} \mathrm{O}, 0.42 ; \mathrm{CuSO}_{4} \cdot 5 \mathrm{H}_{2} \mathrm{O}, 0.391 ; \mathrm{FeCl}_{3}, 1.45 ;$

$\mathrm{Na}_{2} \mathrm{MoO}_{4} \cdot 2 \mathrm{H}_{2} \mathrm{O}, 1.26$; yeast extract, 30 . The synthetic wastewater was used to simulate 
middle strength domestic wastewater. Based on the component of the synthetic wastewater, $\mathrm{TOC} / \mathrm{TN}(\mathrm{C} / \mathrm{N})$ ratio of the influent in the experiments was $6.5 \pm 0.5$.

\subsection{MBBR experimental set-up and operation}

Three bench-scale MBBRs of $12 \mathrm{~L}$ were employed with a cubic-shaped polyurethane sponge $(15 \times 15 \times 15 \mathrm{~mm})$ serving as biofilm carriers. Sponges with a density of $28 \mathrm{~kg} / \mathrm{m}^{3}$ with 90 cells per $25 \mathrm{~mm}$ were purchased from Joyce Foam Pty, Australia. Average specific surface area of a sponge cube was $0.846 \mathrm{~m}^{2} / \mathrm{g}$. Following this, three reactors were filled with non-acclimatized sponge carriers at the filling fraction of $10 \%(\mathrm{R} 1), 20 \%(\mathrm{R} 2)$, and $30 \%(\mathrm{R} 3)$, and began by inoculating activated sludge with the initial mixed liquor suspended solids (MLSS) of $2.8 \mathrm{~g} / \mathrm{L}$. The activated sludge derived from a secondary sedimentation tank at a local municipal wastewater treatment plant, located in Tianjin, China. Firstly, the sponge carriers were acclimatized to the synthetic wastewater for 15 days, with the hydraulic retention time (HRT) and the aeration flow set at $24 \mathrm{~h}$ and $0.09 \mathrm{~m}^{3} / \mathrm{h}$, respectively. Three reactors were then operated continuously in parallel with HRT of $12 \mathrm{~h}$ and an aeration flow of $0.09 \mathrm{~m}^{3} / \mathrm{h}$. The dissolved oxygen (DO) concentration in R1, R2 and R3 ranged from 5.0-6.5 $\mathrm{mg} / \mathrm{L}$. The $\mathrm{pH}$ was adjusted to around 7.0 with $\mathrm{NaCO}_{3}$ or $\mathrm{H}_{2} \mathrm{SO}_{4}$ every day.

\subsection{Analytical methods}

TOC in the influent and effluent was measured using a TOC analyzer (TOC-VWP, Shimadzu, Japan). $\mathrm{NH}_{4}{ }^{+}-\mathrm{N}, \mathrm{NO}_{2}{ }^{-}-\mathrm{N}$ and $\mathrm{NO}_{3}{ }^{-}-\mathrm{N}$ were examined with an ion chromatograph analyzer (ICS-1500, THEMORS, US). The analysis of MLSS and mixed liquor volatile suspended solids (MLVSS) was done according to Standard Methods (APHA, 2005). AGBS

and volatile attached-growth biomass (VAGBS) in each sponge carrier were obtained by hand squeezing. In the meantime the sponge was rinsed with ultrapure water. Total nitrogen (TN) removal efficiency, simultaneous nitrification and denitrification (SND), nitrification rate (NR) and denitrification rate (DNR) were calculated using (1)-(4):

TN removal efficiency $=\left(1-\frac{\left[\mathrm{NH}_{4}^{+}-\mathrm{N}\right]_{\text {eff }}+\left[\mathrm{NO}_{2}^{-}-\mathrm{N}\right]_{\text {eff }}+\left[\mathrm{NO}_{3}^{-}-\mathrm{N}\right]_{\text {eff }}}{\left[\mathrm{NH}_{4}^{+}-\mathrm{N}\right]_{\mathrm{inf}}+\left[\mathrm{NO}_{2}^{-}-\mathrm{N}\right]_{\mathrm{inf}}+\left[\mathrm{NO}_{3}^{-}-\mathrm{N}\right]_{\mathrm{inf}}}\right) \times 100$ 
$\mathrm{SND}=\left(1-\frac{\left[\mathrm{NO}_{2}^{-}-\mathrm{N}\right]_{\mathrm{eff}}+\left[\mathrm{NO}_{3}^{-}-\mathrm{N}\right]_{\text {eff }}-\left[\mathrm{NO}_{2}^{-}-\mathrm{N}\right]_{\mathrm{inf}}-\left[\mathrm{NO}_{3}^{-}-\mathrm{N}\right]_{\mathrm{inf}}}{\left[\mathrm{NH}_{4}^{+}-\mathrm{N}\right]_{\mathrm{inf}}-\left[\mathrm{NH}_{4}^{+}-\mathrm{N}\right]_{\text {eff }}}\right) \times 100$

$\mathrm{NR}=\frac{\left[\mathrm{NH}_{4}^{+}-\mathrm{N}\right]_{\mathrm{inf}}-\left[\mathrm{NH}_{4}^{+}-\mathrm{N}\right]_{\mathrm{eff}}}{\mathrm{VS} * \mathrm{~T}}$

$\mathrm{DNR}=\frac{\left[\mathrm{NH}_{4}^{+}-\mathrm{N}\right]_{\mathrm{inf}}-\left[\mathrm{NH}_{4}^{+}-\mathrm{N}\right]_{\mathrm{eff}}+\left[\mathrm{NO}_{2}^{-}-\mathrm{N}\right]_{\mathrm{inf}}+\left[\mathrm{NO}_{3}^{-}-\mathrm{N}\right]_{\mathrm{inf}}-\left[\mathrm{NO}_{2}^{-}-\mathrm{N}\right]_{\mathrm{eff}}-\left[\mathrm{NO}_{3}^{-}-\mathrm{N}\right]_{\mathrm{eff}}}{\mathrm{VS} * \mathrm{~T}}$

Where $\left[\mathrm{NH}_{4}{ }^{+}-\mathrm{N}\right]_{\mathrm{inf}}, \quad\left[\mathrm{NO}_{2}^{-}-\mathrm{N}\right]_{\text {inf }}$ and $\left[\mathrm{NO}_{3}^{-}-\mathrm{N}\right]_{\text {inf }}$ are $\mathrm{NH}_{4}{ }^{+}-\mathrm{N}, \quad \mathrm{NO}_{2}^{-}-\mathrm{N}$ and $\mathrm{NO}_{3}^{-}-\mathrm{N}$ concentrations in the influent $(\mathrm{mg} / \mathrm{L}),\left[\mathrm{NH}_{4}{ }^{+}-\mathrm{N}\right]_{\mathrm{eff}},\left[\mathrm{NO}_{2}{ }^{-}-\mathrm{N}\right]_{\mathrm{eff}}$ and $\left[\mathrm{NO}_{3}{ }^{-}-\mathrm{N}\right]_{\text {eff }}$ are $\mathrm{NH}_{4}{ }^{+}-\mathrm{N}$, $\mathrm{NO}_{2}^{-}-\mathrm{N}$ and $\mathrm{NO}_{3}^{-}-\mathrm{N}$ concentrations in the effluent $(\mathrm{mg} / \mathrm{L}), \mathrm{T}$ is the HRT of the reactors during the operation (h), VS is the sum of MLVSS and VAGBS concentrations (mg/L). The units of $\mathrm{NR}$ and DNR were $\mathrm{mg} \mathrm{NH}_{4}{ }^{+}-\mathrm{N} / \mathrm{mg} \mathrm{VS} / \mathrm{h}$ and $\mathrm{mg} \mathrm{NO}{ }_{\mathrm{x}}{ }^{-} \mathrm{N} / \mathrm{mg} \mathrm{VS} / \mathrm{h}$, respectively, $\left(\mathrm{NO}_{\mathrm{x}}{ }^{-}-\mathrm{N}\right.$ : the sum of $\mathrm{NO}_{2}^{-}-\mathrm{N}$ and $\left.\mathrm{NO}_{3}{ }^{-} \mathrm{N}\right)$.

\section{Results and discussion}

\subsection{Effect on TOC removal}

Fig. 1 shows the variations in TOC concentrations and removal efficiencies in the three MBBRs during continuous operation at a HRT of $12 \mathrm{~h}$ and aeration flow of $0.09 \mathrm{~m}^{3} / \mathrm{h}$. It can be seen that all MBBRs (R1, R2 and R3) performed well in terms of TOC removal with efficiencies ranging from $88.9 \%$ to $98.6 \%$. The efficiencies of TOC on average in R1, R2 and R3 were $93.8 \pm 2.5 \%, 95.8 \pm 1.4 \%$ and $94.9 \pm 2.2 \%$, respectively. It is evident that TOC removals in the three reactors were marginally different. Nevertheless, considering the average removal efficiencies, there was still a slight difference in the treatment efficiencies of TOC with the different filling fractions. Results indicated R2 filled with $20 \%$ sponge carriers had on average the highest TOC removal efficiency.

\section{Fig. 1.}

\subsection{Effect on nitrogen removal}

\subsection{1 $\mathrm{NH}_{4}{ }^{+}-\mathrm{N}, \mathrm{TN}$ removal and SND performance}

Fig. 2 depicts the various $\mathrm{NH}_{4}{ }^{+}-\mathrm{N}$, TN concentrations as well as their removal efficiencies and SND performance in the three MBBRs. The average treatment efficiencies of $\mathrm{NH}_{4}{ }^{+}-\mathrm{N}$, 
TN and SND performance are shown in Table 1. As far as $\mathrm{NH}_{4}{ }^{+}-\mathrm{N}$ removal was concerned, $\mathrm{R} 1, \mathrm{R} 2$ and $\mathrm{R} 3$ performed well in removing $\mathrm{NH}_{4}{ }^{+}-\mathrm{N}$ up to $100 \%$ during the operation lasting 90 days (see Fig. 2 (a)). From Table 1, it was apparent that there was no obvious difference in the average $\mathrm{NH}_{4}{ }^{+}-\mathrm{N}$ removal efficiencies of $\mathrm{R} 1, \mathrm{R} 2$ and $\mathrm{R} 3$. Therefore the filling fraction exerted little influence on $\mathrm{NH}_{4}{ }^{+}-\mathrm{N}$ removal and TOC removal. However, of the three reactors, R2 demonstrated the most stable treatment performance (Fig. 2 (b)) and highest removal efficiency of $97.9 \pm 2.6 \%$ on average. Overall, the removal efficiencies of $\mathrm{NH}_{4}{ }^{+}-\mathrm{N}$ and TOC followed the same order: R2 > R3 >R1.

It is well known that SND occurs in the MBBR system because of the oxygen concentration gradient within biocarriers, which results in an anoxic microenvironment in the biocarriers' inner layers (Khan et al., 2011). TN removal mainly depends on SND performance in aerobic MBBRs. TN removal and the three MBBRs' SND performance were investigated during the operation. From Fig. 2 (b) and (c), it was found that the maximum TN removal and SND for the three MBBRs were up to $98 \%$ and $100 \%$, respectively. Chu and Wang (2011a) found that average ammonium removal efficiency of 90\% was achieved at HRT of $18.5 \mathrm{~h}$ in the MBBR with $11.3 \%$ biodegradable polymer carriers from wastewater with low $\mathrm{COD} / \mathrm{N}$ ratio of around 0.7 , while the average $\mathrm{TN}$ removal efficiency was $74.6 \%$ due to SND limited by the rate of denitrification. Chu and Wang (2011b) also investigated the TN removal in MBBR filled with $20 \%$ the polyurethane carriers at an HRT of $14 \mathrm{~h}$. Results showed only $1-20 \%$ of TN removal was achieved due to the shortage of organic carbon source (3.7-4.2 of COD/TN ratio in the influent).

The results in Table 1 confirmed that $\mathrm{R} 3$ removed the most $\mathrm{TN}$ and correspondingly enjoyed the best SND performance, followed by R2 and R1. The results also indicated TN removal efficiencies in R1, R2 and R3 did accord with SND performance. Therefore, despite $\mathrm{R} 1, \mathrm{R} 2$ and $\mathrm{R} 3$ demonstrating the approximate average $\mathrm{NH}_{4}{ }^{+}-\mathrm{N}$ efficiency of over $95 \%, \mathrm{R} 2$ and R3 were better at removing TN than R1 because their SND capability proved to be 
superior.

Furthermore, TN in the effluent mainly consisted of $\mathrm{NH}_{4}{ }^{+}-\mathrm{N}$ and $\mathrm{NO}_{3}{ }^{-}-\mathrm{N}$ with the concentration of $\mathrm{NO}_{2}{ }^{-}-\mathrm{N}$ being less than $0.6 \mathrm{mg} / \mathrm{L}$ during the entire operation. Meanwhile, average $\mathrm{NH}_{4}{ }^{+}-\mathrm{N}$ removal efficiency of over $95 \%$ was achieved, which meant that TN removal and SND were limited by the rate of denitrification. Based on the results shown in Table 1, it is evident that there was no obvious difference in TN removal between a filling fraction of $20 \%$ (R2) and 30\% (R3), which resulted from the higher filling fraction affecting the substrates' transfer to the biomass into biocarriers. Under the same aeration flow the biocarriers' fluidization in R2 was better than R3 due to there being fewer biocarriers.

Overall, the filling fraction wielded little influence on TOC and $\mathrm{NH}_{4}{ }^{+}-\mathrm{N}$ removal, while mainly affected TN removal and SND performance. Considering the treatment efficiency, the optimum filling fraction was $20 \%$ for the sponge-based MBBR.

\section{Table 1.}

\section{Fig.2.}

\subsubsection{Nitrification rate and denitrification rate performance}

The nitrification and denitrification rates in three reactors were investigated. Three MBBRs with $10 \%, 20 \%$ and $30 \%$ filling fraction revealed good nitrification rate from day 5 with the range of $1.01-1.43 \mathrm{mg} \mathrm{NH}_{4}{ }^{+}-\mathrm{N} / \mathrm{L} / \mathrm{h}$, while denitrification rate was below $0.91 \mathrm{mg}$ $\mathrm{NO}_{\mathrm{x}}{ }^{-}-\mathrm{N} / \mathrm{L} / \mathrm{h}$ before day 10 and was mainly stable above $1.00 \mathrm{mg} \mathrm{NO}{ }_{\mathrm{x}}{ }^{-} \mathrm{N} / \mathrm{L} / \mathrm{h}$ after day 10 . This can result from the denitrifying bacteria growth process in the inner sponge carriers. The results indicated that the filling fraction had no significant effect on the nitrification performance of three MBBRs. The slightly higher nitrification rate with $1.26 \pm 0.10 \mathrm{mg} \mathrm{NH}_{4}{ }^{+}-$ $\mathrm{N} / \mathrm{L} / \mathrm{h}$ on average was observed in R2 with $20 \%$ filling fraction. Compared to nitrification rate of the reactors, denitrification rate was affected more obviously by the filling fractions of three MBBRs under the same condition. Denitrification rate of R1 was lowest in three MBBRs and there was no obvious difference between R2 and R3 during the operation period. 
This result was consistent with TN removal of the three MBBRs (Fig.2 (b)). In addition, the mean values of nitrification and denitrification rates in R1, R2 and R3, which showed that nitrification rate was higher than denitrification rate. It meant that the denitrification capacity is the controlling factor that affects the MBBR system's nitrogen removal ability. In addition, the difference between nitrification and denitrification rate decreased as the filling fraction increased, with the minimum occurring in R3. It can account for the highest TN removal and SND performance on average in R3.

In the meantime, NR and DNR performance differed from nitrification and denitrification capabilities in three MBBRs. NR and DNR of three MBBRs reduced with filling fraction increasing. NR in three MBBRs with 10\%, 20\% and 30\% filling fraction ranged from 1.071.47, 0.58-0.73 and 0.42-0.58 $\mathrm{mg} \mathrm{NH}_{4}{ }^{+}-\mathrm{N} / \mathrm{g}$ VS /h, respectively. Correspondingly, DNR was lower than NR with the range of 0.87-1.34, 0.44-0.70 and 0.33-0.54 $\mathrm{mg} \mathrm{NO}_{\mathrm{x}}{ }^{-}-\mathrm{N} / \mathrm{g}$ VS $/ \mathrm{h}$. The results further demonstrated that DNR was the limited factor for SND performance which was responsible for $\mathrm{TN}$ removal in aerobic MBBR. The average NR for R1, R2 and R3 was $1.31 \pm 0.12,0.65 \pm 0.05$ and $0.50 \pm 0.04 \mathrm{mg} \mathrm{NH}_{4}{ }^{+}-\mathrm{N} / \mathrm{g} \mathrm{VS} / \mathrm{h}$, respectively. Nevertheless, the biomass in three MBBRs showed lower DNR than NR $(1.12 \pm 0.11,0.60 \pm 0.06$ and $0.47 \pm 0.05$ $\mathrm{mg} \mathrm{NO}{ }_{\mathrm{x}}^{-}-\mathrm{N} / \mathrm{g} \mathrm{VS} / \mathrm{h}$, respectively). It can be seen that $\mathrm{R} 1$ presented the highest $\mathrm{NR}$ and DNR, followed by R2 and R3. Therefore, NR and DNR decreased with the amount of biomass in MBBRs.

Based on the above results, it can be concluded that the $20 \%$ filling fraction was recommended for aerated sponge-based $\mathrm{MBBR}$, with a nitrification rate of $1.26 \pm 0.10 \mathrm{mg}$ $\mathrm{NH}_{4}{ }^{+}-\mathrm{N} / \mathrm{L} / \mathrm{h}$ and a denitrification rate of $1.16 \pm 0.13 \mathrm{mg} \mathrm{NO}{ }_{\mathrm{x}}^{-}-\mathrm{N} / \mathrm{L} / \mathrm{h}$ on average.

\subsection{Effect on biomass growth}

Table 2 shows the MLSS, MLVSS and biomass growth on sponges in the three MBBRs. It was very clear that MLSS, MLVSS, AGBS and VAGBS increased when the filling fraction rose. The results indicated the biomass in the sponge carriers played the major rule in how 
well the MBBR performed, because the amount of biomass in the sponge carriers was 5.6 to 6.0 bigger than the suspended sludge. This finding is based on the values of MLVSS and TVAGBS as summarized in Table 2. The suspended sludge in MBBR mainly originated from the detachment. Under the higher filling fraction, collisions between carriers occur at a higher rate, which can produce an increase in biofilm detachment (Martín-Pascual et al., 2015). Therefore the larger sponge carriers volume resulted in higher MLSS and MLVSS (R3> R2> R1).

For the biomass attached to the sponge carriers, the AGBS and VAGBS amounts per gram sponge were similar for R1 and R2, both of which were higher than R3 (Table 2). The results in Table 2 demonstrated that more biomass grew in the biocarriers in $\mathrm{R} 1$ and $\mathrm{R} 2$ than $\mathrm{R} 3$. This may have been due to better mass transfer in R1 and R2 under the same aeration flow of 0.09 $\mathrm{m}^{3} / \mathrm{h}$. It is well known that the movement of the carriers is achieved through aeration, which is very important for the transport of substrates to the biofilm and biomass growth in carriers. This is because the substrates (e.g. oxygen, carbon and nitrogen sources) have to permeate through the carriers' inside and then be transported to the microbial cells for metabolism (Nicolella et al., 2000).

The amounts of AGBS and VAGBS on per gram sponge of R2 were slightly higher than $\mathrm{R} 1$ and this was due to shear force. The same aeration flow of $0.09 \mathrm{~m}^{3} / \mathrm{h}$ provided a higher shear force for R1 than R2, because the filling fraction of R1 (10\%) was smaller than that of R2 (20\%). Meanwhile, the total AGBS and VAGBS amounts (the values of TAGBS and TVAGBS in Table 2) in R2 were much higher than in R1, which resulted in R2 performing much better than R1.

It was observed from Table 2 that the total VAGBS and VAGBS in the reactors increased with the filling fraction. Of the three reactors, $\mathrm{R} 2$ revealed the highest value of total biomass with 2.122 $\pm 0.674 \mathrm{~g}$ VAGBS/L. However, TN removal in R3 was slightly higher than R2 while the removals of TOC and $\mathrm{NH}_{4}{ }^{+}-\mathrm{N}$ were a little less than $\mathrm{R} 2$ (Table 1). This indicated 
that a larger filling fraction may not favour the treatment efficiencies which affected the transport of substrates in reactors under the same type of operation.

\section{Table 2}

\section{Conclusions}

- The filling fraction wielded only a slight influence on TOC and $\mathrm{NH}_{4}{ }^{+}-\mathrm{N}$ removal but demonstrated a more significant effect on the TN removal and SND performance;

- NR was higher than DNR in three MBBRs while DR was affected more significantly than nitrification rate by the filling fractions of three MBBRs;

- NR and DNR all decrease with increasing the filling fraction;

- The amount of attached biomass on sponge carriers in the three reactors varied with the filling fraction;

- The filling fraction of $20 \%$ is recommended for the aerated-MBBR in terms of the treatment efficiencies of TOC, $\mathrm{NH}_{4}{ }^{+}-\mathrm{N}$, TN and SND performance.

\section{Acknowledgements}

The work was supported by Tianjin Chenjian University, School of Environmental and Municipal Engineering and University of Technology, Sydney, Centre for Technology in Water and Wastewater, School of Civil and Environmental Engineering.

\section{References}

1. APHA, AWWA, WEF, 2005. Standard Methods for the Examination of Water and Wastewater, 20th ed. American Public Health Association, Washington, DC.

2. Bertin L., Lampis S., Todaro D., Scoma A., Vallini G., Marchetti L., Majone M., Fava F., 2010. Anaerobic acidogenic digestion of olive mill wastewaters in biofilm reactors packed with ceramic filters or granular activated carbon. Water Res. 44, 4537-4549.

3. Chen S., Sun D., Chung J., 2008. Simultaneous removal of COD and ammonium from landfill leachate using an anaerobic-aerobic moving-bed biofilm reactor system. Waste 
Manag. 28, 339-346.

4. Chen X., Kong L., Wang X., Tian S., Xiong Y., 2015. Accelerated start-up of moving bed biofilm reactor by using a novel suspended carrier with porous surface. Bioprocess Biosyst. Eng. 38, 273-285.

5. Chu L., Wang J., 2011a. Nitrogen removal using biodegradable polymers as carbon source and biofilm carriers in a moving bed biofilm reactor. Chem. Eng. J. 170, 220-225.

6. Chu L., Wang J., 2011b. Comparison of polyurethane foam and biodegradable polymer as carriers in moving bed biofilm reactor for treating wastewater with a low $\mathrm{C} / \mathrm{N}$ ratio. Chemosphere. 83, 63-68.

7. Guo W., Ngo H.H., Dharmawan F., Gay C., 2010. Palmer Roles of polyurethane foam in aerobic moving and fixed bed bioreactors. Bioresour. Technol. 101 (2010) 1435-1439.

8. Khan, J.S., Ilyas, S., Javid, S., Visvanathan, C., Jegatheesan, V., 2011. Performance of suspended and attached growth MBR systems in treating high strength synthetic wastewater. Bioresour. Technol. 102, 5331-5336.

9. Lee, W., Kang, S., Shin, H., 2003. Sludge characteristics and their contribution to microfiltration in submerged membrane bioreactors. J. Membrane Sci. 216, 217-227.

10. Leyva-Díaz J.C., Calderón K., Rodríguez F.A., González-López J., Hontoria E., Poyatos J.M., 2013. Comparative kinetic study between moving bed biofilm reactor-membrane bioreactor and membrane bioreactor systems and their influence on organic matter and nutrients removal. Biochem. Eng. J. 77, 28-40.

11. Luo, Y., Guo, W., Ngo, H.H., Nghiem, L.D., Hai, F.I., Kang, J., Xia, S., Zhang, Z., Price, W.E., 2014. Removal and fate of micropollutants in a sponge-based moving bed bioreactor. Bioresour. Technol. 159, 311-319.

12. Luo Y., Qi J., Ngo H.H., Nghiem L.D., Hai F.I., Price W.E., Wang J., Guo W., 2015. Evaluation of micropollutant removal and fouling reduction in a hybrid moving bed biofilm reactor-membrane bioreactor system. Bioresour. Technol. 191, 355-359. 
13. Martín-Pascual J., Leyva-Díaz J.C., Manuel J., 2015. Treatment of urban wastewater with pure moving bed membrane bioreactor technology at different filling ratios, hydraulic retention times and temperatures. Ann. Microbiol. 1-7.

14. McQuarrie J.P., Boltz J.P., 2011. Moving bed biofilm reactor technology: process applications, design, and performance. Water Environ. Res. 83(6), 560-575.

15. Nicolella C., Loosdrecht M.C.M., Heijnen J.J., 2000. Wastewater treatment with particulate biofilm reactors. J. Biotechnol. 8, 1-33.

16. Ngo, H.H., Guo, W., Xing, W., 2008. Evaluation of a novel sponge-submerged membrane bioreactor (SSMBR) for sustainable water reclamation. Bioresour.Technol. 99, $2429-2435$.

17. Nguyen T.T., Ngo H.H., Guo W.S., Johnston A., Listowski A., 2010. Effects of sponge size and type on the performance of an up-flow sponge bioreactor in primary treated sewage effluent treatment. Bioresour.Technol. 101, 1416-1420.

18. Ødegaard H., Rusten B., Westrum T., 1994. A new moving bed biofilm reactor: Applications and results. Water Sci. Technol. 29(10-11), 157-165.

19. Rouse J.D., Burica O., Strazar M., Levstek M., 2007. A pilot-plant study of a moving-bed biofilm reactor system using PVA gel as a biocarrier for removals of organic carbon and nitrogen. Water Sci. Technol. 55, 135-141.

20. Wu W., Yang F., Yang L., 2012. Biological denitrification with a novel biodegradable polymer as carbon source and biofilm carrier. Bioresour.Technol. 118, 136-140. 


\section{Figure captions}

Fig. 1. TOC concentration variations and removal efficiencies in the three MBBRs

Fig.2. Variations of $\mathrm{NH}_{4}{ }^{+}-\mathrm{N}, \mathrm{TN}$ concentrations and their removal efficiencies as well as SND performance in R1, R2 and R3: (a) $\mathrm{NH}_{4}{ }^{+}-\mathrm{N},(\mathrm{b}) \mathrm{TN}$, and (c) SND 


\section{ACCEPTED MANUSCRIPT}

* influent

$\diamond$ R1 effluent

- R2 effluent

$\triangle \mathrm{R} 3$ effluent $\multimap \mathrm{R} 1 \multimap \mathrm{R} 2 \multimap \mathrm{R} 3$

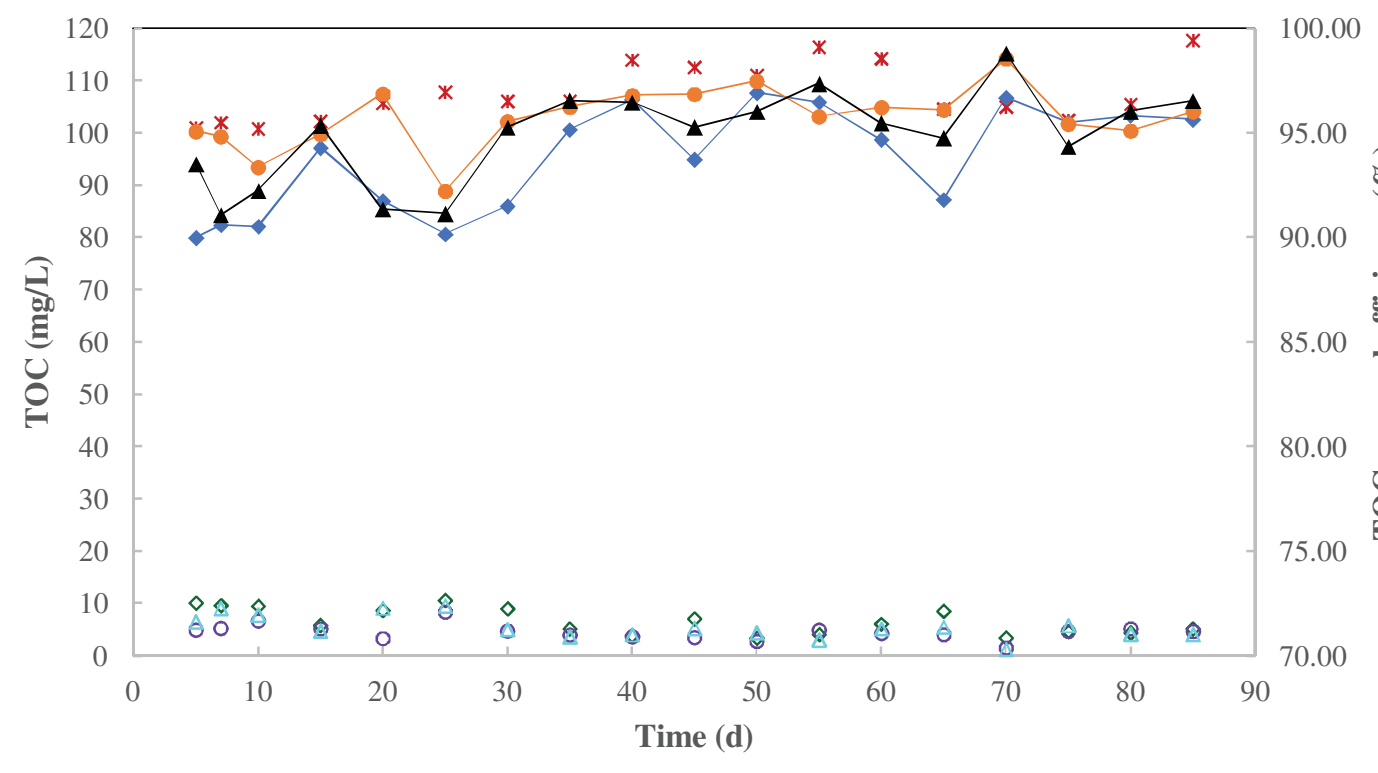

Fig. 1 


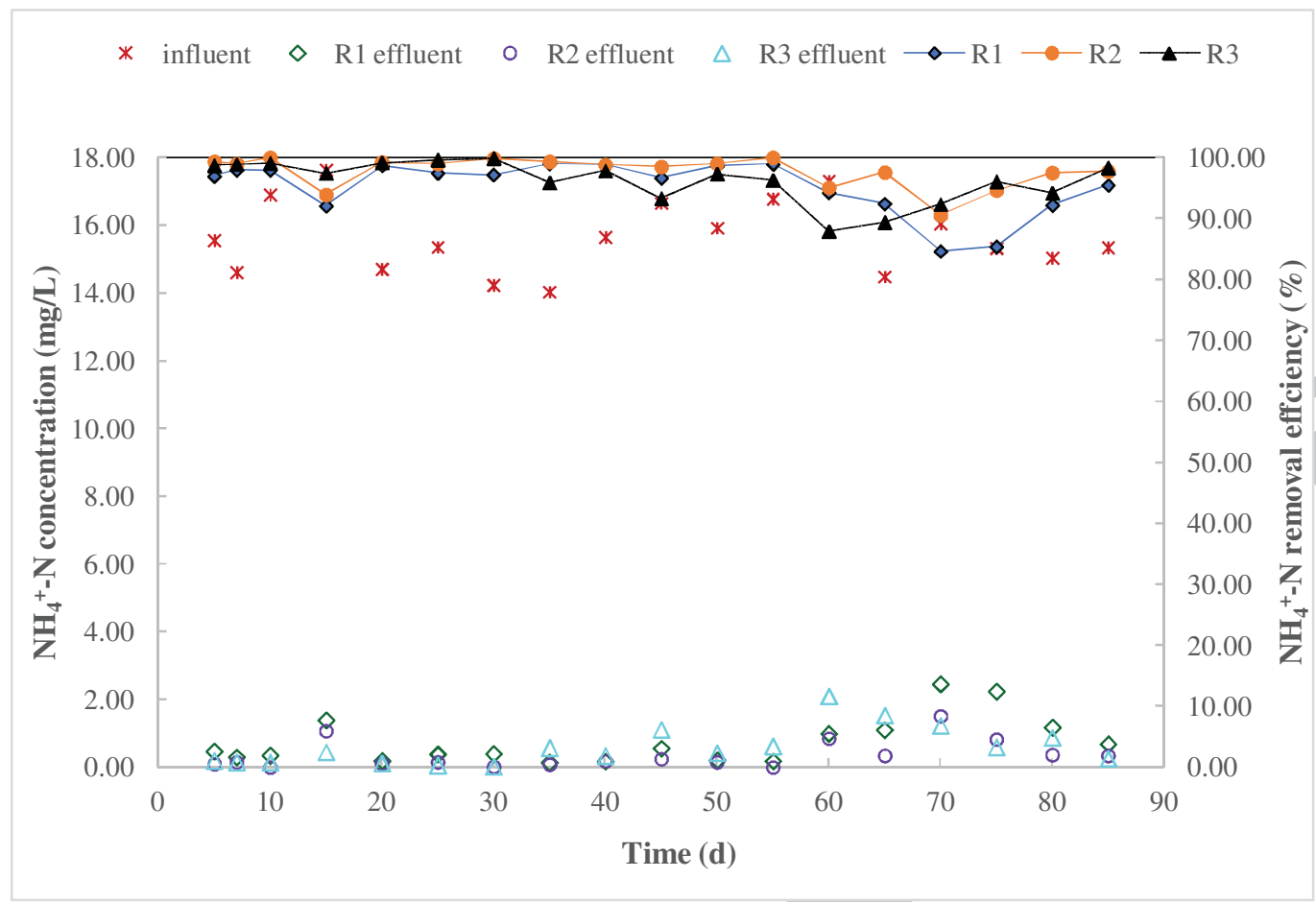

(a)

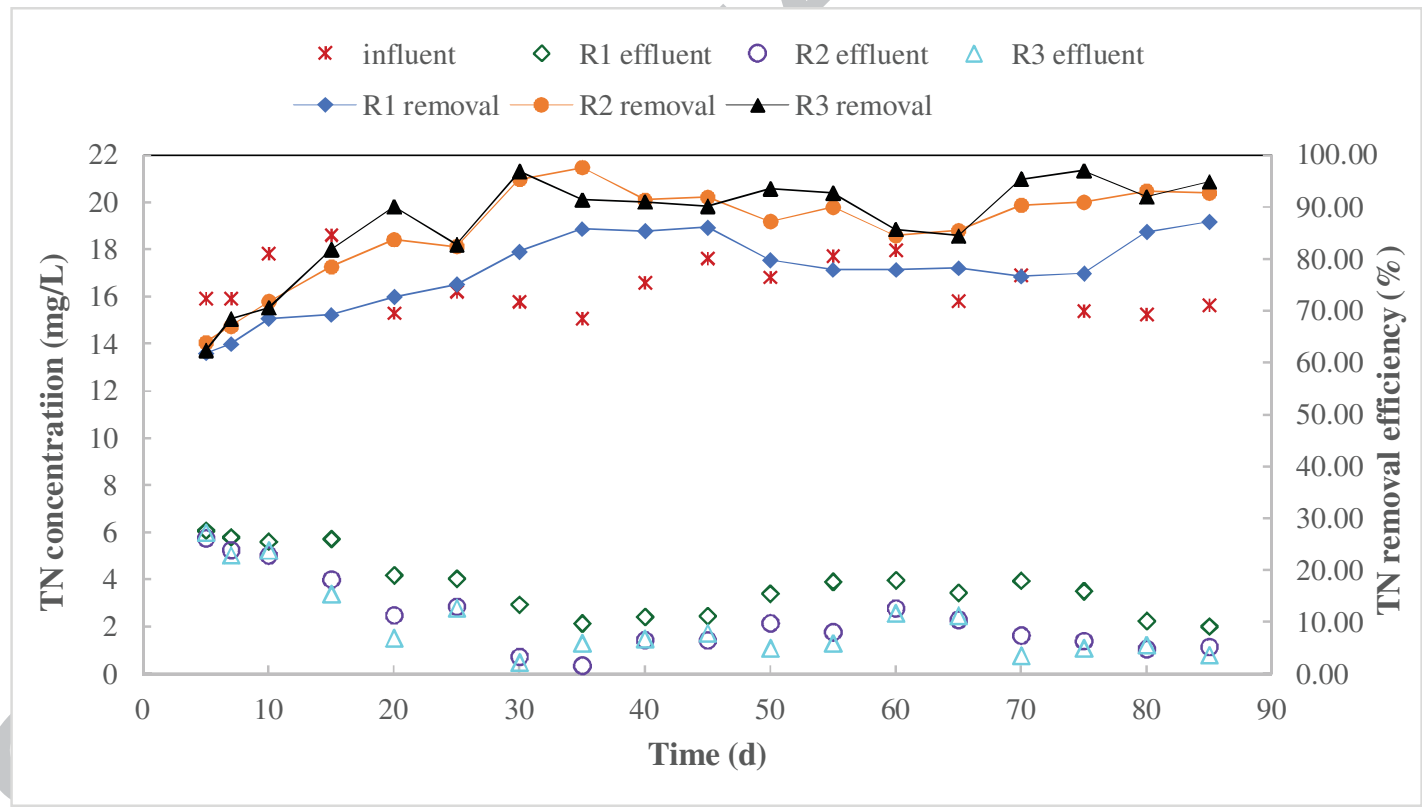

(b) 


\section{ACCEPTED MANUSCRIPT}

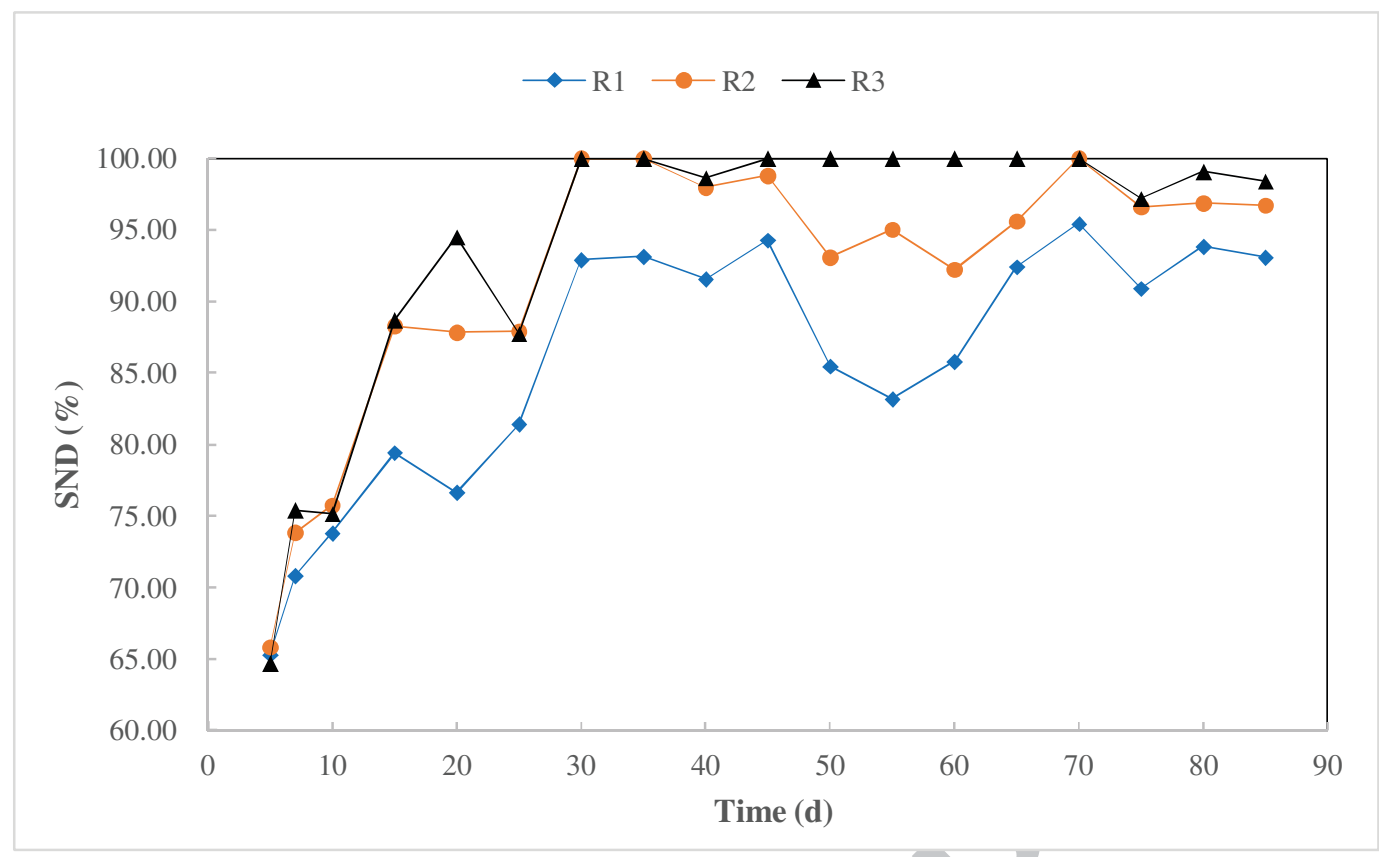

(c)

Fig.2. 
Table 1. $\mathrm{NH}_{4}{ }^{+}-\mathrm{N}, \mathrm{TN}$ removal efficiencies and SND of the three MBBRS (mean data)

\begin{tabular}{lccc}
\hline & $\mathrm{NH}_{4}{ }^{+}-\mathrm{N}$ removal (\%) & $\mathrm{TN}$ removal (\%) & $\mathrm{SND}(\%)$ \\
\hline R1 & $95.3 \pm 4.6$ & $77.2 \pm 7.4$ & $85.5 \pm 8.7$ \\
R2 & $97.9 \pm 2.6$ & $85.5 \pm 9.3$ & $91.3 \pm 9.4$ \\
R3 & $96.2 \pm 3.4$ & $86.7 \pm 9.9$ & $93.3 \pm 10.2$ \\
\hline
\end{tabular}

Table 2. MLSS, MLVSS, AGBS and VAGBS in the three MBBRS (mean data)

\begin{tabular}{lcccccc}
\hline $\begin{array}{c}\text { MLSS } \\
(\mathrm{g} / \mathrm{L})\end{array}$ & $\begin{array}{c}\text { MLVSS } \\
(\mathrm{g} / \mathrm{L})\end{array}$ & $\begin{array}{c}\text { aAGBS } \\
(\mathrm{g} \text { AGBS/g } \\
\text { sponge })\end{array}$ & $\begin{array}{c}\text { aVAGBS } \\
(\mathrm{g} \text { VAGBS/g } \\
\text { sponge })\end{array}$ & $\begin{array}{c}\text { TAGBS } \\
\text { (g AGBS/L) }\end{array}$ & $\begin{array}{c}\text { TVAGBS } \\
\text { (g VAGBS/L) }\end{array}$ \\
\hline R1 & $0.161 \pm 0.058$ & $0.142 \pm 0.053$ & $0.342 \pm 0.056$ & $0.287 \pm 0.076$ & $0.957 \pm 0.157$ & $0.802 \pm 0.213$ \\
R2 & $0.336 \pm 0.220$ & $0.294 \pm 0.198$ & $0.349 \pm 0.062$ & $0.294 \pm 0.076$ & $1.954 \pm 0.349$ & $1.648+0.424$ \\
R3 & $0.406 \pm 0.308$ & $0.351 \pm 0.274$ & $0.312 \pm 0.069$ & $0.253 \pm 0.084$ & $2.619 \pm 0.551$ & $2.122 \pm 0.674$ \\
\hline \multicolumn{7}{l}{ aAGBS: the AGBS amount in per gram sponge, }
\end{tabular}

aVAGBS: the VAGBS amount in per gram sponge,

TAGBS: the AGBS concentration in the reactor,

TVAGBS: the VAGBS concentration in the reactor. 


\section{Highlights}

- The filling fraction exhibited significant effect on TN removal and SND performance.

- DNR was affected more obviously than NR by the filling fractions.

- The difference between NR and DNR decreased with the filling fraction increasing.

- DNR is the controlling factor that affecting nitrogen removal performance of MBBR.

- The carriers showed the largest amount of biomass in the $20 \%$ filling fraction MBBR. 